\title{
Characterization of Fly Ash for its Mineralogy, Physical and Chemical properties - A Review
}

\author{
K. Theresa* and S. Sheeba \\ Department of Soil Science and Agricultural Chemistry, Tamil Nadu Agricultural University, \\ Coimbatore - 641 003, Tamil Nadu, India \\ *Corresponding author
}

\section{A B S T R A C T}

Keywords

Mineralogy,

Physical and chemical properties.

Article Info

Accepted:

04 October 2017

Available Online:

10 December 2017
Poor nutritional status is a major cause determinant of crop productivity of a soil. Many waste materials containing essential plant nutrients are available in huge quantities which when applied at appropriate rates can enhance the nutrient status as well as other soil properties. Yields of several crops were required to increase addition of fly ash which alleviates nutrient deficiencies in plants although the response varied from soil to soil. Thus, the use of fly ash in agriculture provides a feasible to improve the soil environment and enhance the crop productivity and also for its safe disposal.

\section{Introduction}

Power is considered as an engine of growth and it is a main focus area for most of the developing countries, including India. The power generation in India has increased from $1362 \mathrm{MW}$ in 1947 to about 2,00,000 MW in 2014 and expected to increase up to $3,00,000$ MW by 2017. Though in last four decades various alternate energy sources have come into the limelight, the hyperbolic use of coal as a prime energy source cannot be counterbalanced. Coal is a major source of energy till date and is expected to remain so in near future. India is the third largest producer of coal and major source of power is generated through coal based thermal power plants. In order to achieve the economic growth of 8-9 per cent, the country's total coal demand has been forecasted to increase from about 730 million tonnes in 2010-11 to about 2000 million tonnes in 2031-32 (India Energy Book, 2012).

\section{Status of fly ash generation}

As per an estimate of FAUP, TIFAC, the annual fly ash generation figures are expected to reach about 225 million tonnes by 2017 (Kumar et al., 2005). In 2016-17 it is expected that India will produce 300-400 million tonnes of fly ash. The ministry of power, Government of India estimates that 1800 million tonnes of coal use will lead to the generation of 600 million tonnes of fly ash by 2031-2032. Not only does this huge 
amount of fly ash create environmental problems it also eats up large tracts of land required for dumping of this waste. About 61.37 per cent of fly ash is being utilized for construction of roads and embankments, production of cement, mine-filling, reclamation of low-lying areas, agriculture, making bricks and tiles and others (CEA Annual Reports, 2013-14). Concentrated efforts have been made by Department of Science and Technology, Government of India to increase the scale and utilization of fly-ash.

A large number of technologies have been developed for gainful utilization and safe management of fly ash under the concerted efforts of Fly Ash Mission of the GOI since 1994. Fly ash was moved from "hazardous industrial waste" to "waste material" category during the year 2000 and during November 2009, it became a saleable commodity. Fly ash utilization has started gaining acceptance, it being 55.79 per cent during 2010-12. Use of fly ash in agriculture provides a feasible alternative for its safe disposal to improve the soil environment and enhance the crop productivity.

Fly-ash has great potentiality in agriculture due to its efficacy in modification of soil health and crop performance. The high concentration of nutrient elements $(\mathrm{P}, \mathrm{K}, \mathrm{Na}$, $\mathrm{Zn}, \mathrm{Ca}, \mathrm{Mg}$ and $\mathrm{Fe}$ ) in fly-ash increases the yield of many agricultural crops. But compared to other sectors, the use of fly-ash in agriculture is limited.

\section{Characterisation of fly ash}

\section{Size distribution and mineralogy of fly ash}

Fly ash is the portion of combustion solid waste residue with small enough particle size to be carried away in the flue gas. Fly ash is a fine powder recovered from the gases of burning coal during the production of electricity. These micron-sized earth elements consist primarily of silica, alumina and iron. Their size varies from a few micrometers to $0.2 \mathrm{~mm}$. These spheres occur individually or form intergrowths. Grains exist in a few per cent of unburned carbonaceous matter. They have different shapes and are generally porous, with pore maximum size of a few micrometers.

X-ray diffractometry (XRD) results indicated the presence of cryptocrystalline aggregates composed of mullite and a small amount of quartz and iron oxides. Iron oxides were observed on the outer surface of spherical forms of aluminosilicate glass in the form of very fine magnetite-hematite inclusions. The bulk density of the tested ash was $2.28 \mathrm{~g} \mathrm{~cm}^{-3}$. Coarse-grain accumulation of fly ash indicates the presence of fine-grained particles, with more than about 70 per cent of the particles finer than $0.075 \mathrm{~mm}$ as compared to soil. Indian fly ashes are predominantly silt-sized fine material, with 60-90 per cent of fly ash particles finer than $0.075 \mathrm{~mm}$ sieve (Rai et al., 2010). The silt-sized particles, low $\mathrm{BD}$, higher $\mathrm{WHC}$, favorable $\mathrm{pH}$, and plant nutrients in fly ash have also been reported by Ram and Masto (2014) as a potential soil amendment agent.

\section{Physical properties of fly ash}

Coal fly ash is comprised of very fine particles, with an average diameter $<10 \mathrm{~mm}$, aggregated into spherical particles of 0.01$100 \mathrm{~mm}$ sizes which are hollow spheres (cenospheres) filled with smaller amorphous particles or crystals (pelospheres). These cenospheres make fly ash particles easily airborne (El-Mogazi et al., 1988). Dubey et al., (1999) collected fly ash from Koradi Thermal Power Station and characterized for its physical properties. Bulk density was between $0.85-1.16 \mathrm{~g} \mathrm{~cm}^{-3}$ and the available 
water holding capacity was between 40.155.6 per cent.

Fly ash generated from various thermal power plants in India was reported to comprise silt in the range of 8-85 per cent, clay 0-10 per cent, sand 7-90 per cent and gravel 0-10 per cent. Bulk density of fly ash varied from 1 to $1.8 \mathrm{~g}$ $\mathrm{cm}^{-3}$, Water holding capacity of the fly ash was generally 49-66 per cent on weight basis, while the moisture retention ranged from 6.1 per cent at 15 bar to 13.4 per cent at $1 / 3$ bar (Prem Kishor et al., 2010). The coal fly ash generally had a silt loam texture, with 65-90 per cent of the particles having diameters of less than $0.010 \mathrm{~mm}$. The specific gravity of fly ash ranged from 2.1 to $2.6 \mathrm{~g} \mathrm{~cm}^{-3}$ and the mean particle density for non-magnetic and magnetic particles is 2.7 and $3.4 \mathrm{~g} \mathrm{~cm}^{-3}$ respectively (Nyambura et al., 2011). Singh et $a l$. , (2012) reported that the specific gravity of fly ash sample was $2.21 \mathrm{~g} \mathrm{~cm}^{-3}$ and bulk density was $1.32 \mathrm{~g} \mathrm{~cm}^{-3}$. Fly ash particles were more than $50 \mu$ in size. The textural analysis showed that the fly ash had a very low specific Brunauer-Emmett-Teller (BET) surface area of $12 \mathrm{~m}^{2} \mathrm{~g}^{-1}$ and low ion exchange capacity of $0.10 \mathrm{meq}^{-1}$ Franus et al., (2014). Fly ash constitutes a varied combination of amorphous and crystalline phases (usually considered as ferroaluminosilicate) and has a matrix similar to soil (Lim and Choi, 2014).

\section{Physico-chemical properties of fly ash}

The physico-chemical properties of fly ash primarily depend on the nature of the parent coal composition from which it comes, and secondly on the conditions under which the coal is combusted. Fly ash is generally grey in colour and mostly alkaline in nature. The alkaline $\mathrm{pH}$ of the fly ash may be due to the presence of $\mathrm{Ca}, \mathrm{Na}$, and $\mathrm{Mg}$ along with other trace elements. $\mathrm{CaO}$ is a major constituent of the fly ash that forms $\mathrm{Ca}(\mathrm{OH})_{2}$ with water and thus attributes to alkalinity (Pandey and Singh, 2010). Fly ash can either be acidic or alkaline, depending on the source of the coal used for combustion, especially the sulphur content of the close relative coal, and the operating condition of the plant (Ram and Masto, 2010). Coal fly ash was alkaline in nature $(\mathrm{pH} 7.85 \pm 0.03)$ with an electrical conductivity of $0.14 \pm 0.02 \mu \mathrm{S} \mathrm{m} \mathrm{m}^{-1}$, water holding capacity of 62 per cent, low bulk density of $0.99 \mathrm{~g} \mathrm{~cm}^{-3}$, and a surface area of $0.96 \mathrm{~m}^{2} \mathrm{~g}^{-1}$ (Rajinder and Goyal, 2014).

\section{Chemical properties of fly ash}

\section{Composition of fly ash}

Ahmaruzzaman (2010) described fly ash as mainly being composed of $\mathrm{Si}, \mathrm{Al}$, and $\mathrm{Fe}$, with a major proportion of $\mathrm{Ca}, \mathrm{K}, \mathrm{Na}, \mathrm{Ti}$, along with other trace elements. Coal fly ash consists of $\mathrm{SiO}_{2}$ (49-67\%), $\mathrm{Al}_{2} \mathrm{O}_{3}$ (16-29 $\%), \mathrm{Fe}_{2} \mathrm{O}_{3}$ (4-10\%), $\mathrm{CaO}(1-4 \%), \mathrm{MgO}$ (0.2-2\%), and $\mathrm{SO}_{3}(0.1-2 \%)$ (Singh and Aggarwal, 2010). A study of coal and fly ash samples, using particle induced X-ray emission spectroscopic technique confirmed that $\mathrm{K}, \mathrm{Ca}$, $\mathrm{Ti}$ and $\mathrm{Fe}$ were present as major elements, whereas, other elements, e.g. V, Cr, $\mathrm{Mn}, \mathrm{Co}, \mathrm{Ni}, \mathrm{Cu}, \mathrm{Zn}, \mathrm{As}, \mathrm{Se}, \mathrm{Rb}, \mathrm{Sr}$ and $\mathrm{Pb}$ were present in trace amounts (Patra et al., 2012).

The basic chemical oxide composition of fly ash expressed as percentage (\%) was as follows: $\quad \mathrm{SiO}_{2}, \quad$ 53.25; $\quad \mathrm{Al}_{2} \mathrm{O}_{3}, \quad 26.76$ $\left(\mathrm{SiO}_{2} / \mathrm{Al}_{2} \mathrm{O}_{3}, 1.99\right) ; \mathrm{Fe}_{2} \mathrm{O}_{3}, 5.98 ; \mathrm{MgO}, 2.29$; $\mathrm{CaO}, 2.88 ; \mathrm{Na}_{2} \mathrm{O}, 0.74 ; \mathrm{K}_{2} \mathrm{O}, 2.82 ; \mathrm{TiO}_{2}$, $1.15 ; \mathrm{P}_{2} \mathrm{O}_{5}, 0.47$; and $\mathrm{SO}_{3}, 0.48$ (Franus et al., 2014).

\section{Nutrient availability in fly ash}

Fly ash has been used as a source of essential plant nutrients. Ash application greatly increased the $\mathrm{P}, \mathrm{K}, \mathrm{B}, \mathrm{Ca}, \mathrm{Mg}, \mathrm{Mn}, \mathrm{Zn}$, 
carbonates, bicarbonates, and sulfates contents of the soil (Khan and Singh, 2001). Yunusa et al., (2006) had reported that the fly ash contained considerable content of macro nutrients $(\mathrm{P}, \mathrm{K}, \mathrm{Ca}, \mathrm{Mg})$ and micronutrients $(\mathrm{Cu}, \mathrm{Zn}, \mathrm{Mn}$ and $\mathrm{Fe})$.

\section{Heavy metal content in fly ash}

Calcium, $\mathrm{K}$, and $\mathrm{Mg}$ are present in coal fly ash in similar or higher concentrations compared to soils and mostly in forms that are readily plant available. Trace elements (TEs) which are essential in plant growth such as $\mathrm{Cu}, \mathrm{Fe}, \mathrm{Mn}, \mathrm{Mo}, \mathrm{Zn}, \mathrm{B}$ occur in coal fly ash in quantities similar or higher than those found in soils, constituting a considerable source of trace elements for plants (Page et al., 1979). Soil is not only considered as a source of nutrients for plants, but as a sink for the removal of contaminants from industrial wastes including fly ash, which may comprise of many of the toxic metals like As, Cd, Co, $\mathrm{Cr}, \mathrm{Cu}, \mathrm{Hg}, \mathrm{Mo}, \mathrm{Ni}, \mathrm{Pb}, \mathrm{V}, \mathrm{Zn}$, etc. These elements are found either on the surface of the ash particles, in the aluminosilicate matrix phase, or in both (Smith, 1987). Nilesh et al., (2012) reported that the heavy metal content of fly ash was based on the parent coal composition from which it is produced and on its coal combustion conditions. Fly ash contains approximately 95-99 per cent oxides of $\mathrm{Si}, \mathrm{Al}, \mathrm{Fe}$ and $\mathrm{Ca}$ and about 0.5 to 3.5 per cent of $\mathrm{Na}, \mathrm{P}, \mathrm{K}$ and $\mathrm{S}$.

Fly ash is a byproduct produced from coal combustion process, and it is an effective resource available in plenty. It is overloaded with beneficial characteristics viz., its physical nature may be useful for changing the problematic soils such as clay and sandy soils and helps to bringing the soils in favour to the crop growth and development, the chemical properties shows that it is highly weighed with all the macro and micronutrients required for the successive growth and development.

\section{References}

Ahmaruzzaman, M. 2010. A review of the utilization of fly ash. Prog. Energy. Combust. Sci., 36: 327-363. Aitken, R.L. and L.C. Bell. 1985. Pl. Soil., 84: 245.

Dubey, P.N., S.P. Sangal, T.K. Sen, S. Chatterji, S. Murali and V.P. Patil. 1999. Physical and chemical properties of koradi fly ash for its utilization in agriculture. Agropedology, 9: 71-76.

El-Mogazi, D., C.A. Gutenmamm and L.H. Weinstein. 1988. A review of physical, chemical and biological properties of fly ash and effect on agriculture ecosystems. Sci. Total. Environ., 74: 137.

Franus, W., W. Maddalena and F. Malgorzata. 2014. Synthesis and characterization of zeolites prepared from industrial fly ash. Environ. Monit. Assess, 186(9): 5721-5729.

Khan, M.R. and W.N. Singh. 2001. Effects of soil application of fly ash on the fusarial wilt on tomato cultivars. Inter. J. Pest Manag., 47: 293-297.

Kumar, V., G. Singh and R. Rai. 2005. Fly ash : a material for another green revolution. Fly ash utilization programme (FAUP), TIFAC, DST, New Delhi.

Lim, S.S. and W.J. Choi. 2014. Changes in microbial biomass, $\mathrm{CH}_{4}$ and $\mathrm{CO}_{2}$ emissions, and soil carbon content by fly ash co-applied with organic inputs with contrasting substrate quality under changing water regimes. Soil Biol. Biochem., 68: 494-502.

Nilesh, K.M., P.D. Sachin, B.S. Dhananjay and B.A. Sanjay. 2012. Effect of fly ash as an admixture in agriculture and the study of heavy metal accumulation in wheat, mung bean and urad beam. Pol. J. Environ. Stud., 21 (6): 1713-1719.

Nyambura, M.G., W.G. Mugera, P.L. Felicia 
and N.P. Gathura. 2011. Carbonation of brine impacted fractional coal fly ash: implications for $\mathrm{C} 02$ sequestration. J. Environ. Manage., 92: 655-664.

Page, A.L., A.A. Elseewi and I.R. Straughan. 1979. Physical and chemical properties of fly ash from coal fires power plants with referrence to environmental impacts. Residue Review., 71: 83-120.

Pandey, V.C. and N. Singh. 2010. Impact of fly ash incorporation in soil systems. Agriculture Ecosystem and Environment., 136: 16-27.

Patra,K.C., T.R. Rautray and P. Nayak. 2012. Analysis of grain grown on fly ash treated soils. Appl. Radiat. Isot., 70: 1797-1802.

Prem Kishor, A.K. Gosh and Dileep Kumar. 2010. Use of Fly Ash in Agriculture: A way to improve soil fertility and its Productivity. As. J. Agric. Res., 4(1): 14.

Rai, A.K., B. Paul and G. Singh. 2010. A study on backfull properties and use of fly ash for highway embankments. J. Adv. Laboratory Res. Bio., 1(2): 110114

Rajinder. K. and D. Goyal. 2014.
Mineralogical Studies of Coal Fly Ash for Soil Application in Agriculture. Particulate Science and Techno: An Inter. J., 33: 76-80.

Ram, L.C. and R.E. Masto. 2014. Fly ash for soil amelioration. A review on the influence of ash blending with inorganic and organic amendments. Earth Science Review., 128: 52-74.

Singh, A and S.B. Agrawal. 2010. Response of mung bean cultivars to fly ash: growth and yield. Ecotox. Environ. Safe., 73: 1950-1958.

Singh, N. and S.B. Raunaq Singh. 2012. Effect of fly ash on sorption behavior of metribuzin in agricultural soils. J. Environ. Sci. Health B., 47: 89- 98.

Smith, I.M. 1987 Trace elements from coal combustion: emissions, Chapter 2. Source of Trace Elements. Coal Research, London.

Yunusa, I.A.M., V. Manoharan, D.L. De Silva, D. Eamus, B.R. Murray and N.P. Nissan. 2008. Growth and elemental accumulation by canola on soil amended with coal fly ash. J. Environ. Qual., 37: 1263-1270.

\section{How to cite this article:}

Theresa, K. and Sheeba, S. 2017. Characterization of Fly Ash for its Mineralogy, Physical and Chemical Properties - A Review. Int.J.Curr.Microbiol.App.Sci. 6(12): 339-343. doi: https://doi.org/10.20546/ijcmas.2017.612.040 